\title{
Integritas Panitia Tarung Bebas
}

\author{
Saortua Marbun ${ }^{1}$ \\ ${ }^{1}$ Sekolah Tinggi Ilmu Ekonomi Triatma Mulya
}

October 9, 2018

\section{Integritas Panitia Tarung Bebas}

\author{
Saortua Marbun(Marbun, 2018) \\ saortuam@gmail.com | http://orcid.org/0000-0003-1521-7694
}

DOI: $10.22541 /$ au.151624089.92438669

(C) 2018 Saortua Marbun

Tahun ini dan tahun mendatang menjadi momen "tarung bebas" bernama Pemilihan Kepala Daerah hingga Pemilihan Kepala Negara, yang dimeriahkan dengan pemelilihan wakil rakyat DPD, DPR, DPRD. Pertarungan elektoral itu ditandai dengan perang opini bermuatan "kepentingan". Tema yang diulas "perlambatan pertumbuhan ekonomi", "utang negara". Para pihak terlibat dalam berebut "piala" kekuasaan lima tahunan. Sementara itu pihak "pemberi kuasa" bergumul karena terabaikan, terpinggirkan, dan tidak terwakili.

Meminjam istilah Ashraf Ghani (2005) yang menyebut bahwa rakyat terus menerus menjadi korban kapitalisme dan demokrasi. Rakyat tidak diuntungkan dari kedua sistem tersebut. Mereka tidak memiliki dana sebagai kapital. Uang hanya digunakan sebagai alat penukar, berbelanja kebutuhan hidup, sembako secukupnya. Upah minimum untuk memenuhi kebutuhan hidup layak masih menjadi perdebatan.

Secara demokratis, rakyat tidak menjadi "pemilik kekuasaan" yang sesungguhnya. Keterlibatan rakyat dalam negara demokrasi hanya sebatas voting. Keuntungan maksimal dari "kekuasaan" justru dinikmati para pemenang pertarungan. Sekali pun kata "rakyat" ribuan kali diucap dan ditulis namun "rakyat miskin" dan "kemiskinan" terasa dijadikan "lipstick" oleh mereka yang sedang "gelojoh kuasa".

Tentu saja, logis, bila "Penyelenggara Tarung Bebas" - dituntut bekerja keras. Kehadiran "mereka" sangat dibutuhkan karena dua kata "Kapitalisme dan Politik" kini sedang berada di arena. Demokrasi itu cenderung dimenangi oleh pemilik modal yang menjadi kontestan atau pemilik modal yang berada di belakang kandidat. Mereka piawai bermain peran, menggunakan berbagai trik dan jurus. Menggoreng identitas, menabur hoaks, kampanye hitam, politik uang dan seterusnya. Realita itu yang menjadi alasan bagi "Panitia" untuk memadu kekuatan, misalnya, mengerahkan Satuan Tugas Antik Politik Uang, anti hoaks, anti politik SARA dan antianti lainnya.

Kita berharap agar kata kunci miskin, kemiskinan, rakyat miskin, petani miskin, nelayan miskin, rakyat lemah, tidak mampu, tidak berdaya - hendaknya tidak dijadikan pelengkap riasan wajah aktor demi mengkatrol elektabilitas. Nominal bantuan, sumbangan, derma, santunan yang diberikan jauh lebih kecil bila dibandingkan dengan "biaya advertorial", nominal itu semakin tidak berarti bila menimbang "manfaat intangible" yang dinikmati "donatur politis" yang muncul menjadi dermawan yang patut di "vote", di "ike". 
Donasi "sembako, pengobatan gratis, pemeriksaan kesehatan gratis" berlabel elektoral itu bagaikan "beberapa butiran nasi" yang jatuh dari jemputan "tidak sebanding dengan sajian" yang terhidang di meja.

Panitia diharapkan menjadi "wasit", menjadi "hakim pertandingan" yang benar, adil, berwibawa, independen, tepat aturan, tepat waktu. Bila wasit "lemah" kita pun tahu akibatnya. Bila hakim di sisi ring tidak adil maka pertarungan menjadi liar. Bila tata tertib permainan tidak ditegakkan, tentu hadiah kemenangan bisa jatuh ke tangan pecundang, curang.

Firman Allah berkata, "Engkau tidak boleh memutarbalikkan keadilan, engkau tidak boleh memandang muka atau menerima suap, karena suap benar-benar membutakan mata orang-orang bijaksana dan memutarbalikkan perkataan orang-orang benar." (sab, c)(Ulangan 16:19, MILT) Negeri ini sangat membutuhkan satgas yang terdiri dari, "Ia yang berjalan dalam kebenaran, dan yang berbicara dalam kejujuran, dia yang menolak keuntungan dari pemeras, yang mengebaskan tangannya dari mengambil uang suap, yang menutup telinganya dari mendengar tentang darah, dan menutup matanya dari melihat yang jahat." (sab, a)(Yesaya $33: 15$, MILT)

Memberantas politik uang, tidak semudah mengatakan, "terima saja uangnya tetapi jangan pilih orangnya." Semua pihak perlu diingatkan bahwa, "karena cinta akan uang ialah sumber segala jenis kejahatan. Ada orang-orang yang sesat dari imannya dan menikam diri mereka dengan berbagai dukacita oleh karena mereka mengejar-ngejar uang." (sab, b)(1 Timotius 6:10, Shellabear) Menerima atau memberi uang dalam konteks demokrasi itu bertentangan dengan ajaran Tuhan. $\left(^{*}\right)$ 


\section{References}

Yesaya 33:15 (Versi Paralel) - Tampilan Ayat - Alkitab SABDA. http://alkitab.sabda.org/verse.php?book=yesaya\&chapter=33\&verse=15, a. URL http://alkitab . sabda.org/verse.php?book=yesaya\&chapter=33\&verse=15. Accessed on Thu, January 18, 2018.

1 Timotius 6:10 (Versi Paralel) - Tampilan Ayat - Alkitab SABDA. http://alkitab.sabda.org/verse.php?book=1b. URL http://alkitab.sabda.org/verse.php?book= 1\%20timotius\&chapter=6\&verse=10. Accessed on Thu, January 18, 2018.

Ulangan 16:19 (Versi Paralel) - Tampilan Ayat - Alkitab SABDA. http://alkitab.sabda.org/verse.php?book=ulangan\&chapter $=16 \&$ verse $=19, \quad$ c. $\quad$ URL http: //alkitab.sabda.org/verse.php?book=ulangan\&chapter=16\&verse=19. Accessed on Thu, January 18, 2018.

Ashraf Ghani. How to rebuild a broken state. Ted Global, July 1, 2005. URL https://www.ted.com/talks/ ashraf_ghani_on_rebuilding_broken_states. Accessed on Thu, January 18, 2018.

Saortua Marbun. Integritas Panitia Tarung Bebas - Mimbar Protestan. Surat Kabar Pos Bali, Jan 11 (6), 2018. 